\title{
Britannia
}

http://journals.cambridge.org/BRI

Additional services for Britannia:

BRITANNIA

Email alerts: $\underline{\text { Click here }}$

Subscriptions: Click here

Commercial reprints: Click here

Terms of use : Click here

\section{Where Do We Go From Here? Recording and Analysing Roman Coins from Archaeological Excavations}

Kris Lockyear

Britannia / Volume 38 / November 2007, pp 211 - 224

DOI: 10.3815/000000007784016494, Published online: 01 March 2010

Link to this article: http://journals.cambridge.org/abstract_S0068113X00001379

How to cite this article:

Kris Lockyear (2007). Where Do We Go From Here? Recording and Analysing Roman Coins from Archaeological Excavations. Britannia, 38, pp 211-224 doi:10.3815/000000007784016494

Request Permissions : $\underline{\text { Click here }}$ 


\title{
Where Do We Go From Here? Recording and Analysing Roman Coins from Archaeological Excavations
}

\author{
By KRIS LOCKYEAR
}

\section{INTRODUCTION}

A ny excavation of a Roman period site is likely to turn up coins, sometimes in copious quantities, and usually one of the chapters towards the back of the report will be dedicated to them. ${ }^{1}$ More rarely, separate monographs may be produced. ${ }^{2}$ The analysis of these finds has been a part of excavation reports for some time ${ }^{3}$ but the origins of current methods lie largely in the late 1960s/70s (see various papers in Coins and the Archaeologist) ${ }^{4} \mathrm{~A}$ quick perusal of recent published reports reveals, however, a remarkable lack of standardisation, both in the cataloguing of the finds and in their analysis. This is in itself not necessarily a 'bad thing' as progress cannot be made if we stick rigidly to a set pattern, but some common ground is needed if we are to conduct comparative analyses. The publication of guidelines for the production of coin reports by English Heritage should be welcome, ${ }^{5}$ not so much as an aid for the handful of specialists producing these reports, but as a weapon in the battle for resources. My dissatisfaction with these guidelines has led to this paper which takes a slightly unusual format. I have taken the opportunity to look back over what we have been doing up to now, then to briefly review the recommendations made in the guidelines before making recommendations of my own. Much of this is well-known to numismatists, and has often been discussed in informal contexts (although not, as far as I am aware, in print) and my aim in writing this paper is to open out the debate in such a way that all archaeologists concerned with the Roman world may be able to contribute. Many of the points discussed are of relevance to finds outside the remit of the guidelines. ${ }^{6}$ I have divided the paper into three main sections. The first two - how to catalogue the coins and how to analyse the coin assemblage - are covered in the guidelines and follow the format mentioned above. The last main section is entitled 'Implications and Interpretation', although it could equally have been called 'Why Archaeologists Should Care'. This is followed by some summary conclusions.

e.g. Burnett et al. 1986.

e.g. Bost and Namin 2002; Butcher 2003; Schulzki 1989.

e.g. St O’Neil 1935.

Casey and Reece 1974. One of the earliest statistical summaries of Roman coin finds was that by Smith 1840 .

5 Brickstock 2004.

6 See also the review by Guest 2005. 


\section{CATALOGUING COINS}

\section{Where are we now?}

Coins, unlike some classes of archaeological material such as pottery or animal bones, are relatively easy to quantify. They are rarely broken or deliberately cut, at least within most Roman assemblages, and a simple count is possible. ${ }^{7}$ The larger problem is identification. When first faced with a shelf full of catalogues, including the ten volumes of Roman Imperial Coinage, the task seems impossible, but given a well-preserved genuine coin and patience it is usually possible to provide a catalogue number, along with a date range and perhaps a place of manufacture and a denomination. The problem lies with the idea of a 'well-preserved genuine coin', for most site finds are not well-preserved, and a significant number will be contemporary copies. There are various ways of dealing with this problem, although one elegant one is the scheme employed by Reece. ${ }^{8}$ If a coin can be identified exactly it is given its catalogue reference, e.g., HK $105 .{ }^{9}$ If it cannot be identified exactly, but is one of that general type of coin, it is listed 'as HK 105'. If it is a good copy it is listed 'copy of HK 105', a copy of that general type is listed 'copy as HK 105'.

For more detailed analysis, however, the large proportion of poorly-preserved coins is problematic. To include only well-identified coins would be to throw away most of our data. To get around this a series of coin-issue periods have been developed. By creating periods which use distinctive features of the coins usually observable on all but the worst examples, it is possible to create a summary listing of the coins from a site. Alison Ravetz used such a scheme in her analysis of fourth-century finds. ${ }^{10}$ The most common schemes in use now are those developed by Richard Reece and John Casey, although others have been developed, such as those by Hammerson and Curnow. ${ }^{11}$ Brickstock provides a comparison between the two main schemes used in Britain. ${ }^{12}$ It is impossible to convert from one scheme to another without resort to the full catalogue. For example, copies of coins are a major problem. Reece would put all radiate copies in his Period 14 (A.D. 275-96) without distinguishing them from genuine coins in the summary lists, whereas Casey puts them in with their prototypes in his Period 18 (A.D. 260273 ) and separates them from the genuine issues. The biggest problem with copies, however, is how to identify them consistently. This is particularly a problem with the period A.D. 330-348. Many copies are very obvious and present no problem but there is, as shown by metallurgical analysis, an unknown number of good copies. Different specialists will have different opinions as to which coins are copies and which are not.

A quick trawl through published reports reveals wide variation in the catalogues. Some, such as the Lydney Park report ${ }^{13}$ or Sabratha, ${ }^{14}$ provide a very detailed catalogue, whereas others provide a full listing but in a very condensed format ${ }^{15}$ (see FIG. 1). Some may provide the summary listing by coin periods as well, ${ }^{16}$ some omit the full catalogue and only provide the summary, and some provide no catalogue at all and only graphs derived from it, ${ }^{17}$ and one recent

\footnotetext{
7 The Beirut report does, however, give an indication of this in a simple three-stage scheme consisting of 'whole', 'broken', and 'fragment': Butcher 2003. 


\begin{tabular}{|c|c|c|c|c|c|c|}
\hline Coin No & Issuer & Denomination & Description & Coin Cat Ref & Date & Condition \\
\hline 47 & & - & $\begin{array}{l}\text { Obv CONSTAN-SPFAVG } \\
\text { Rev GLORI-AEXER-CITVS } \\
\text { SF No } 80.67 \text { Site A context ooI }\end{array}$ & As LRBC.I.I 34 & $337-4 I$ & $\mathrm{w} / \mathrm{w}$ \\
\hline 48 & & - & $\begin{array}{l}\text { Obv CONSTAN-SPFAVG } \\
\text { Rev VICTORIAEDDAVGGQNN } \\
\text { SF No } 80.59 \text { Sitc B context } 505\end{array}$ & As LRBC. I. I 38 & $345-8$ & $\mathrm{sw} / \mathrm{sw}$ \\
\hline 49 & & - & $\begin{array}{l}\text { Obv DNCONSIIANA-NSPFAVG } \\
\text { Rev FELTEMP REPARATIO } \\
\text { SF No } 80.20 \text { Site A context } 002\end{array}$ & L.RBC. 2.35 & $348-50$ & uw/uw \\
\hline 50 & $\begin{array}{l}\text { Constans/ } \\
\text { Constantius II }\end{array}$ & - & $\begin{array}{l}\text { Obv } \\
\text { Rev VICTORIAEDDAVGGQNN } \\
\text { SF No } 80.17 \text { Site A context } 002\end{array}$ & As LRBC. 1.137 & $346-8$ & $\mathrm{vw} / \mathrm{ew}$ \\
\hline $5 \mathrm{I}$ & & - & $\begin{array}{l}\text { Obv } \\
\text { Rev VICTORIAEDDAVGGQNN } \\
\text { SF No } 80.93 \text { Site C context } 626\end{array}$ & As I.RBC. I, 137 & $346-8$ & $\mathrm{c} / \mathrm{sw}$ \\
\hline 52 & $\begin{array}{l}\text { Constantius II, } \\
\text { caes }\end{array}$ & - & $\begin{array}{l}\text { Obv FLIVLCONSTANTIVSNOBC } \\
\text { Rev GLOR-IAEXERC-I'VS } \\
\text { SF No } 80.25 \text { Site A context oOr }\end{array}$ & LRBC.I. 552 & $330-5$ & $w / w$ \\
\hline 53 & Constantius II & - & $\begin{array}{l}\text { Obv CONSTANT-IVSAVG } \\
\text { Rev VICTORIAEDDAVGGQNN } \\
\text { SF No 81.34 Rampart context } 1004\end{array}$ & LRBC.I.448 & $346-8$ & sw/uw \\
\hline 54 & & - & $\begin{array}{l}\text { Obv DNCONSTAN-TIVSPFAVG } \\
\text { Rev FELTEMPRE-PARATIO } \\
\text { SF No } 80.38 \text { Sitc A context } 009\end{array}$ & As LRBC. 2.76 & $353-60$ & $\mathrm{sw} / \mathrm{sw}$ \\
\hline 55 & & - & SF No 80.15 Site A context 002 & As LRBC. 2.76 & $353-60$ & $\mathrm{sw} / \mathrm{sw}$ \\
\hline 56 & & - & as 54 No 80.5 I Site A context oro & As LRBC. 2.76 & $353-60$ & uw/uw \\
\hline 57 & & - & as 54 & As LRBC. 2.76 & $353-60$ & $\mathrm{w} / \mathrm{w}$ \\
\hline 58 & Theodora & - & $\begin{array}{l}\text { Obv FLMAXTHEO-DORAEAVG } \\
\text { Rev PIETAS ROMANA } \\
\text { SF No } 8 \text { I.65 Rampart context } 1006\end{array}$ & LRBC.I.120 & $337-4 \mathrm{r}$ & sw/uw \\
\hline
\end{tabular}

COINS STRUCK FROM 348 to 364
$21 \quad$ CK Amiens

$2,3(1 * 2), 5(3)$, as $8(3), 9$, as $9,13,18(2), 19$, as $19(3 * 1), 20$.

$29(2), 30,30(\mathrm{a})(3), 32(10), 33(27 * 33), 34(5 * 2), 35(24 * 13), 36$

$37\left(2^{*}\right), 39(2 * 1), 40(1 * 5), 41\left(1^{*} 3\right), 46(1 * 1), 47,48$, as 49,50

$(5 * 2), 51$ (3), 53, $55(1 * 1), 56(3), 57$, as $57,58(10)$, as 58 (4)

$59\left(3^{*}\right), 60(3), 62(1 * 2), 63(2), 66(2), 67,72(1 * 15)$, as $77(1 * 3)$, as 87 .

51 CK Lyon

$178(3), 185,193(1 * 2), 194(2 *), \operatorname{var}(1 * 2), 201,208(2), 211(1 * 4)$

$213\left(2^{*}\right), 215(2), 218,221,226(1 *), 235(2), 237,252(5), 253(2)$,

$254\left(1^{*} 7\right), 265,270(2)$, as $270(2), 272$.

404 , as $415,455(1 * 3), 456(1 *), 457(1 * 2), 460(3), 461,464(2)$.

$603,604(3), 636,662(2 *), 680,687(3)$, as $689(4)$

$884(2), 890,918,922,930,935\left(1^{*}\right)$.

$1121,1216(2), 1218(2)$.

1683,1688 .

$2039(2), 2055(2)$

$2490,2496,2504$ (2), 2505, 2507.

2295,2309

Obv. IM CAE MAGNENTIVS AVG, Rev. VICTORIA AVG ..

ROMANOR, mm. TR

Reverses from: VICTORIA AVGGG (1), VIRTVS AVGVSTI (1), VOTIS V MVLTIS X (1), VOT XX MVLT XXX (1).

394 Bronze: Reverses regular but coins otherwise partly illegible: FELICITAS REIPVBLICE $(2 * 2)$ FEL TEMP REPARATIO Fallen horseman $(14 * 108)$, Galley $(3 * 7)$, Hut $(2 * 4)$, Phoenix on globe $\left(6^{*} 14\right)$, Phoenix on pyre $(6 * 22)$, SALVS DD NN AVG ET CAES (1*4), SPES REIPVBLICAE $(13 * 128)$ VICTORIAE DD NN AVG ET CAES $(3 * 37)$, reverse illegible $(5 * 13)$

1742 Bronze: Reverses irregular but coins otherwise partly illegible: FELICITAS REIPVBLICE $(5 * 5)$, FEL TEMP REPARATIO Fallen horseman (191*1309) (of which one is overstruck on Gloria Exercitus, and two have obverses of Carausius II), Galley (4), VICTORIAE DD NN AVG ET CAES (11*130), reverses illegible $(41 * 48)$.

COINS STRUCK FROM 364 to 378
38 CK Trier
$82(6), 83(2), 85,94,95,96(1 * 1), 97(7)(4), 98(1 *), 100,104$, $105,107(2), 108,109,113,118(2), 121(a), 124,125$.

FIG. 1. Comparison of the detailed catalogue from Lydney (Casey and Hoffman 1999) with the more condensed type from Richborough (Reece 1981). (C Society of Antiquaries of London and Institute of Archaeology, London, respectively) 
report accidentally omitted the catalogue and provided no graphs either. ${ }^{18}$ The Catterick report is exceptional in providing summary listings by both the main period schemes. ${ }^{19}$ London is poorly served as generally only summary data are published, often using Hammerson's scheme which makes comparison with other sites difficult. The Cirencester report is frustrating. Although a reasonably detailed catalogue of the coins from a large number of Cirencester excavations is published, ${ }^{20}$ they are organised into eight groups rather than the 50 sites used both in the analysis of the lists ${ }^{21}$ and the spatial plots. ${ }^{22}$ As a result one is unable to recreate the data-sets analysed without recourse to the unpublished archive. The most important point here, however, is that if the principal catalogue is published in sufficient detail, summarisation of the list into any or all of the schemes is possible. Any report without a detailed coin list should be regarded as seriously deficient.

As can be seen, an attempt to standardise this situation is needed, and indeed the majority of the English Heritage guidelines are dedicated to this aim. Before going on to look at these guidelines, I would like to flag up one item which they omit. It is becoming more common for only some of the coins from an excavation to be catalogued, usually those deemed to be in key stratigraphic units for the dating and phasing of the site. For example, for the Borough High Street excavations in Southwark Hammerson notes that only 15 per cent of the coins had been cleaned, although with the aid of x-ray images 74 per cent could be identified. ${ }^{23}$ It is unknown how many may have been more accurately identified if more resources had been available. This development must be resisted at all costs. All the work on comparing site lists, discussed below, depends on complete lists. Partial lists cannot be analysed in any meaningful way. In some cases where there has been large-scale truncation of deposits, coins in residual contexts may be the main evidence we have for the missing levels (e.g., in London ${ }^{24}$ ). Much of the subtle and nuanced interpretation of the Beirut material relies on having the full lists. ${ }^{25}$

\section{What do the guidelines suggest?}

The English Heritage guidelines suggest three levels of catalogue. The full catalogue with detailed information on die-axes and so on, a shorter catalogue which is a trimmed-down version of the full one, and what the guidelines call a 'spreadsheet', which is in fact the summary by coin periods discussed above (a spreadsheet being a piece of computer software, and there being no reason to use this rather than a proper database, or some other form of graphics package). The full version may be published, or placed in the archive. If archived, the shorter version should be published. The summary tables should be published in any case.

The guidelines list what should be recorded. Some items of information would be regarded as essential by all specialists, principally the coin identification according to the standard catalogues $^{26}$ and its identification code, usually the site code and the small find number. Other items are more debatable. The English Heritage guidelines are adamant that coin wear should be

18 Curteis 2005.

19 Brickstock 2002. The difficulty in preparing the Catterick report was the impetus for the commissioning of the English Heritage guidelines (P.R. Wilson pers. comm.).

20 Reece 1998a.

21 Reece 1998 b

22 Guest 1998.

23 Hammerson 2002, 233.

24 Perring pers. comm.

25 Butcher 2003.

26 The coin catalogue from Lobs Hole, obtainable from the Heritage Network as it was accidentally omitted from the report (Curteis 2005), omits this key piece of information rendering it more-or-less useless for further analysis. 
recorded and provide a seven-level scheme. ${ }^{27}$ The problem with coin wear is ensuring consistency of recording, particularly between different specialists. Reece recorded wear for the Fishbourne report but abandoned it when analysing the coins from Portchester as it was extremely difficult to be consistent. ${ }^{28}$ I have yet to see a coin report which makes much use of coin-wear data, apart from the occasional observation that such-and-such a coin is highly worn and might, therefore, be residual or that a group of coins were virtually unworn and might represent a dispersed hoard. It is probably worthwhile to attempt to record wear in as simple a way as possible with these caveats in mind. The weight of coins from excavations is also problematic. Are we recording the dirty coin, mud and all, or when it has been brushed, or when it has been chemically stripped of its corrosion products? Again, time and money is an issue. The diameter of the coin is possibly of more use when publishing copies as this attribute is sometimes used in their study.

How should coin legends be recorded? An example of a silver denarius of Trajan, RIC 238, will have the obverse legend IMP TRAIANO AVG GER DAC PM TR P. Numismatists cataloguing a museum collection or an important hoard would differentiate between the legend as it should be, and the legend as it survives on the coin by placing the damaged sections in brackets, e.g., [IMP TRAIANO AVG] GER DAC PM TR P. This is because hoards and museum collections are often used in detailed analyses of coin series and such data may be of relevance, and it is this level of recording which is recommended by the guidelines. Site finds are rarely used in such analyses, largely because preservation is comparatively poor. Recording legends in any way increases the time needed to catalogue an assemblage and of course increases the cost. I would argue that unless the coin seems to be particularly rare or unusual, this level of detail is unnecessary.

As discussed, copies will always be a problem however they are catalogued. The use of inverted commas around the dates to indicate copies as recommended by the English Heritage guidelines, however, will create problems at publication stage when the text is mutilated by an over-zealous editor.

It is in the production of the summary lists by period ('spreadsheets') that the English Heritage guidelines are most controversial. As noted above, conversion between the main schemes is impossible without using the full catalogue. The guidelines, however, suggest the adoption of a third hybrid scheme (pp. 12-21) which has 36 categories which separate out genuine coins from copies. For such a scheme to be useful existing coin lists would have to be retro-converted. To enforce a new set of periods seems a backwards step, and they are unlikely to be widely adopted.

\section{Recommendations}

Whether the specialist prefers to use index cards in the first instance, or to use direct data entry, it is likely that all would now employ some form of database package. Indeed, three 'database formats' are provided in the English Heritage guidelines (pp. 22-3). Two have a simple flat file data structure and one is in fact a screen shot of an Access data entry form and gives no indication of the underlying data structure. These database schemas are poorly designed and do not allow the full strength and functionality of a modern relational database package to be realised. An excellent schema was published some years ago by Ryan, ${ }^{29}$ although it may need minor modification for use in a post-excavation situation. The development of powerful PCbased database packages now allows this schema to be used effectively. If the database is well designed, it would be easy to produce catalogues conforming to almost any of the proposed formats providing all the necessary data have been recorded. An additional benefit of using a

27 Brickstock 2004, table 1.

28 Reece 1971, 1984, pers. comm.

291988. 
properly-constructed relational database is the minimisation of effort at the data-entry stage. So, for example, use of a table of legends means that each one need only be entered once and not repeated for every coin that exhibits that legend. ${ }^{30}$ This information can be recalled at will, although without the specifics of preservation.

The accuracy of identification is an interesting problem which was mentioned above. In database terms we are trying to record 'fuzzy data'. Reece's scheme outlined above is elegant but not entirely problem-free. There are various unpublished subtleties to distinguish between shades of accuracy in identification. For example, CK $275^{31}$ is a coin of the Gloria Romanorum type struck in Lyons. If the mint-mark could not be read, it would be catalogued 'as CK 275'. A coin of that type which was definitely from Lyons, but where we cannot read the exact mint-mark would be catalogued 'as CK 276'. ${ }^{32}$ There are various more straightforward ways of resolving this problem using a database package. For example, Terrence Volk's database system records levels of certainty for almost every field. ${ }^{33}$ This seems more complex than is needed, although perhaps recording accuracy of key fields such as the mint might be the way forward. However accuracy is recorded, it would, again, be simple to get printed output to reflect this in any way desired.

It is in the production of the summary lists that using a well-designed and well-constructed database system would be enormously beneficial. Provided the catalogue records the necessary basic data, it would be possible to create the summary lists in any format desired by constructing and saving the appropriate query. Once written, summary lists could be generated at the click of a mouse button and the entire debate concerning the merits or otherwise of the various schemes would become irrelevant. Additionally, linking a well-formed database to a GIS package would enable intra- and inter-site analyses to be undertaken, and the data could be easily copied across into statistical packages. Archiving these databases should be undertaken by whichever national body is responsible - the Archaeological Data Service in the UK for example.

In an ideal world, what would I wish for? If we could agree a standard database schema for the recording of site finds, and if all sites recorded using this scheme archived their data with one central body such as the ADS, then how the lists were published would become almost irrelevant, as we could easily download the data and import it into our favoured database package (it is essential to note the difference between the database schema and the software used to implement it). In a really ideal world, we could then begin to input existing site lists, hoards, and perhaps the data from the Portable Antiquities Scheme ${ }^{34}$ to build up a resource of immense value. Wales has shown the way with the IARCW database which has recorded over 50,000 Iron Age and Roman coins from sites, hoards and single finds.

ANALYSIS

\section{Where are we now?}

Just as the cataloguing of finds has largely fallen into two camps, so has the development of techniques of analysis. Some prefer to rely entirely on the production and interpretation of coin histograms (e.g., the Lydney, Wroxeter, and Sabratha reports cited above), whereas Richard Reece

30 Rogers $(1998,182)$ notes that it took 'two weeks of part-time typing' to enter all the legends in RIC vol. 3 into a database table.

$31 \mathrm{CK}=L R B C$ part 2, Hill et al. 1972.

32 Reece pers. comm.

33 Volk 1994-5.

34 www.finds.org 
has developed a whole series of different comparative techniques. ${ }^{35}$ Reece has been attempting to overcome two problems: first, how to compare many sites and coin periods simultaneously; secondly, how to assess variation against some form of norm or average. In the process he has had to deal with the problem of 'closure', i.e., if the early periods have an above-average percentage of the total assemblage, then the later periods will, of course, have to be below-average. It is possible, however, that the later periods taken on their own exhibit an average profile.

Reece's latest method, originally published in Britannia, ${ }^{36}$ has now gained widespread acceptance, and has been adopted by other scholars. ${ }^{37}$ It can be equally well applied to coin hoards as well as site finds, although, obviously, not at the same time. ${ }^{38}$ In this method, an average coin loss by coin period is calculated. ${ }^{39}$ This average is whatever background with which you wish to compare your individual sites/hoards, e.g., excavations in Cirencester, sites across the Empire, or hoards of a particular date. These figures are then converted to cumulative percentages. Individual sites are plotted by calculating their cumulative percentage profile, and then subtracting the average from it. Although there is nothing essentially wrong with this

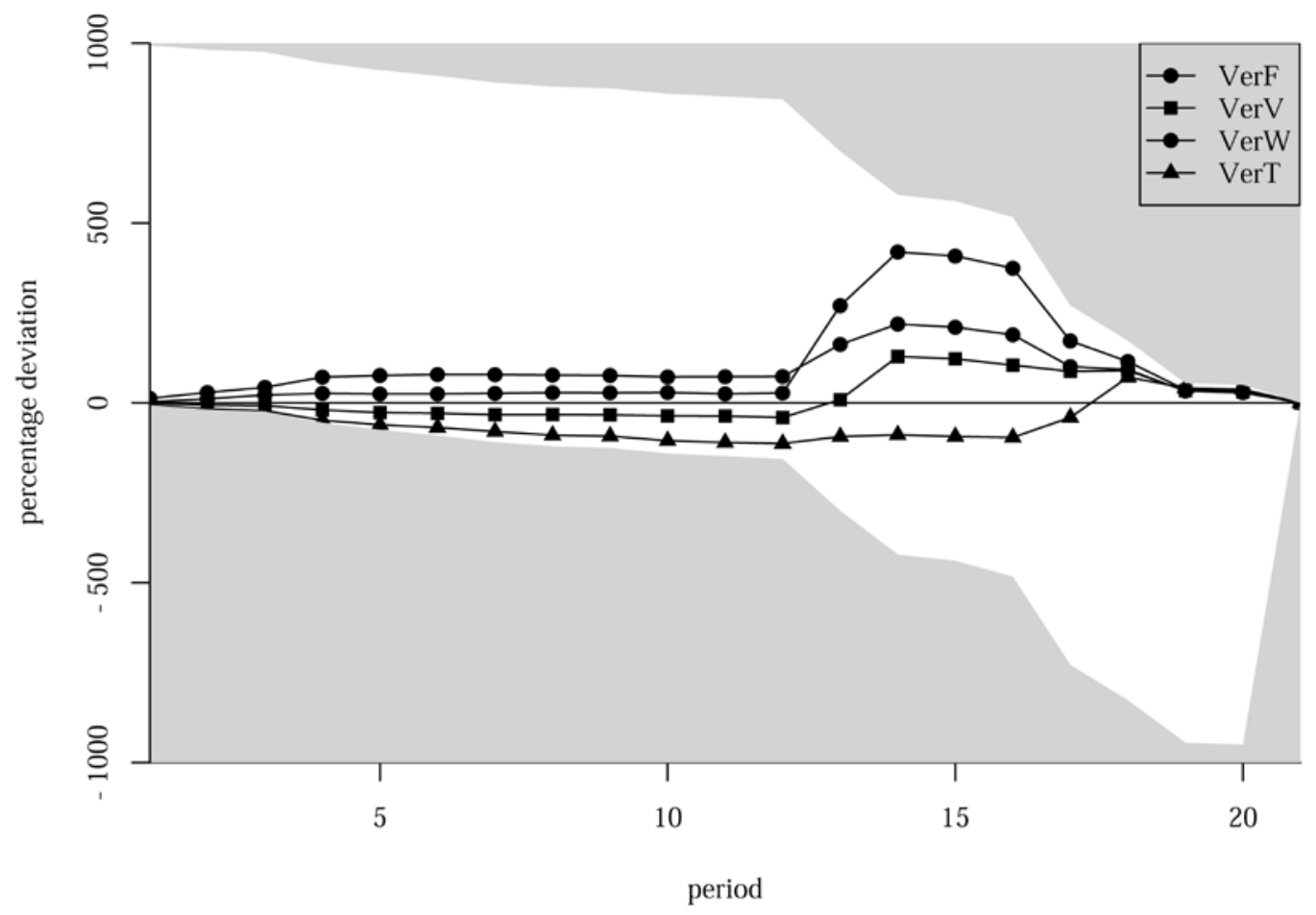

FIG. 2. Four sites from Verulamium plotted according to Reece's Britannia method. No data points can lie in the regions shaded grey. These regions were created by assuming 100 per cent of the coins in Period 1 for the upper limit, and 100 per cent in Period 21 for the lower limit.

See Lockyear 1996, 61-72 for an overview.

Reece 1995b.

e.g. Esmonde Cleary 2001.

Reece 1995a.

Reece 1993. 
method, one has to be very aware of how the graph has been constructed, its limitations, and how to read it. By subtracting the average from the site/hoard values one creates two large areas on the graph where no points may be plotted (see FIG. 2), and the problem of closure is still an issue. One way of tackling closure is to split the list into two and recalculate the graphs, ${ }^{40}$ although this raises the question of where to make the split. ${ }^{41}$

The use of more sophisticated techniques such as cluster and correspondence analysis has been applied and recommended but not widely adopted in coin studies, ${ }^{42}$ although it has gained some acceptance in pottery, glass, and small finds studies. ${ }^{43}$ The availability of free software (the package R) might encourage more widespread use. ${ }^{44}$ There have been a few attempts at intra- and inter-site spatial analysis ${ }^{45}$ but again this has not become commonplace despite the advent of GIS.

\section{What do the guidelines suggest?}

The English Heritage guidelines are mainly concerned with the production of coin histograms and/or bar charts - the two types of graph are wrongly treated as being the same thing in the guidelines. Their recommendation that bar charts rather than line graphs be used as they are easier to 'read' (p. 15) overlooks the advantages of being able to plot multiple sites on the same line graph, whether one uses Reece's method or plain cumulative percentages, ${ }^{46}$ and hardly represents the cutting edge of data analysis. The recommended format stacks bars for copies onto the bars for genuine coins.

\section{Recommendations}

Although I champion the use of techniques such as Correspondence Analysis, it is not principally in the realm of techniques of analysis that I feel we need to move on, but in our basic units of analysis. The coin periods discussed represent the date the coins were struck, not the date that the coins arrived at the site, or the date of their deposition. Although all coin specialists acknowledge this fact, it is rarely examined in any detail. ${ }^{47}$ Tables of coins by site phase are remarkably rare (for an exception see Table 1). ${ }^{48}$ With pottery we could perhaps suggest that a particular type of pot would have an average use-life of so many years. The use-life of coins, however, depends on the details of monetary history along with the intrinsic worth of the metal in them.

FIG. 3 shows this using hoard data. Each horizontal line represents a hoard, its starting point the oldest coin in the hoard, its ending point the hoards' closing date. The number of hoards per period is not representative in this figure. As can be seen, during the first two centuries A.D. coins were circulating for a considerable time and it was not unusual to have coins well over a hundred years old in a hoard. Nero's debasement in A.D. 64 had little immediate effect, but by the reign of Hadrian further debasements had made it worth the state's effort to systematically remove pre-64 silver coins from circulation. Only the debased legionary denarii of Mark Antony were left in circulation. The general population did not care, however, and continued to hoard

\footnotetext{
40 e.g. Reece 2003.

41 The problem of closure is one that has caused much debate in statistics and has yet to be satisfactorily resolved: Aitchison 1986. See also Baxter 2003, 75-7.

42 Lockyear 2000; Ryan 1982.

43 e.g. Cool and Baxter 1995, 1999, 2002; Pitts 2005; Pitts and Perring 2006.

44 Baxter 2006.

45 Guest 1998; Hodder and Reece 1977, 1980; Ryan 1988.

46 cf. Lockyear 1996.

47 See Butcher 2003 for a detailed discussion of the issue.

48 Hammerson 1996, 157-8.
} 
TABLE 1. ROMAN COINS FROM 15-23 SOUTHWARK STREET, BY REIGN AND SITE PHASE (after Hammerson 1996, table 19.1).

\begin{tabular}{|c|c|c|c|c|c|c|c|c|c|c|c|c|c|c|}
\hline \multirow{3}{*}{ Coin date } & \multicolumn{14}{|c|}{ Site phases and dating } \\
\hline & \multirow{2}{*}{$\begin{array}{l}\text { Pre- } \\
\text { C1 } \\
2\end{array}$} & \multicolumn{3}{|c|}{ A.D. $43-85$} & \multirow[b]{2}{*}{6} & \multicolumn{3}{|c|}{ Late C1-Early C2 } & \multicolumn{2}{|l|}{$\mathrm{C2}$} & \multicolumn{2}{|c|}{ Late Roman } & $\begin{array}{l}\text { Dark } \\
\text { earth }\end{array}$ & \multirow{2}{*}{$\begin{array}{l}\text { Post- } \\
\text { Roman } \\
15\end{array}$} \\
\hline & & 3 & 4 & 5 & & 7 & 8 & 9 & 10 & 11 & 12 & 13 & 14 & \\
\hline Pre-Claudian & 1 & 1 & & & & 1 & 1 & & & & & & & 3 \\
\hline Claudius (41-54) & & 3 & & & 6 & & 1 & & 3 & 1 & & 1 & & 3 \\
\hline Nero (54-69) & & & 1 & & 3 & & 2 & & 2 & & & & & 2 \\
\hline $\begin{array}{l}\text { Vespasian/Titus } \\
(69-81)\end{array}$ & & & & & 1 & & 3 & 1 & 4 & & 1 & & & 4 \\
\hline Domitian (81-96) & & $1 *$ & $1 *$ & & & & & & 3 & & & & 1 & 1 \\
\hline Trajan (96-117) & & & & & & & & & & & & & & 1 \\
\hline Hadrian (117-38) & & & & & & & & & & & 1 & & & \\
\hline Antonine (138-93) & & & & & & & & & & 1 & & & & \\
\hline $193-253$ & & & & & & & & & 1 & & 2 & & 1 & 3 \\
\hline $283-296$ & & & & & & & & & & & 1 & & & \\
\hline $296-330$ & & & & & & & & & & & 1 & & & \\
\hline $330-341$ & & & & & & & & & & $1 *$ & 1 & & & 4 \\
\hline $341-350$ & & & & & & & & & & & 1 & & & 1 \\
\hline $350-364$ & & & & & & & & & & & & & 1 & 3 \\
\hline $364-402$ & & & & & & & & & & & & 1 & & \\
\hline
\end{tabular}

(The coins marked with an asterisk are obviously problematic but could not be discussed by Hammerson in his article)

these coins: they are found in hoards closing right into the early third century. During the third century the stable denarius system collapsed, after the introduction of a coin commonly known as the radiate, the emperor being depicted wearing a radiate crown. From then on the base-metal coinage, which forms the overwhelming majority of site finds, went through a series of reforms and collapses, such as the FEL TEMP REPARATIO ('Happy times are here again') issues between A.D. 348 and 364 marked in FIG. 3. These later issues seem to have remained in circulation for a much shorter period than the earlier coins.

The implication of this graph is that although issue periods may be easier to define (and perhaps more 'objective'), perhaps we should be striving towards coin-use periods. Early analyses of site finds by Reece used four phases of coinage with Phase A incorporating the stable period of the denarius system, Phase B the unstable radiate period, Phase C the period of Diocletian's and Constantine's reforms, and Phase D the remainder of the fourth century. ${ }^{49}$ This scheme has proved very robust and clearly shows differences between towns, rural sites, and especially temples. ${ }^{50}$ Other phases have been suggested but not followed up. ${ }^{51}$ The robustness of this scheme derives from the fact that the four phases in part reflect periods of coin use, not just coin production.

Work on the site finds from Beirut integrates the stratigraphic information and pottery data with the coinage to produce a more nuanced appraisal of the material. ${ }^{52}$ This is an excellent example of how integrating the various strands of information can add to our understanding

\footnotetext{
Reece 1973, 1974

Reece 1993.

Reece 1991, 2.

Butcher 2003.
} 


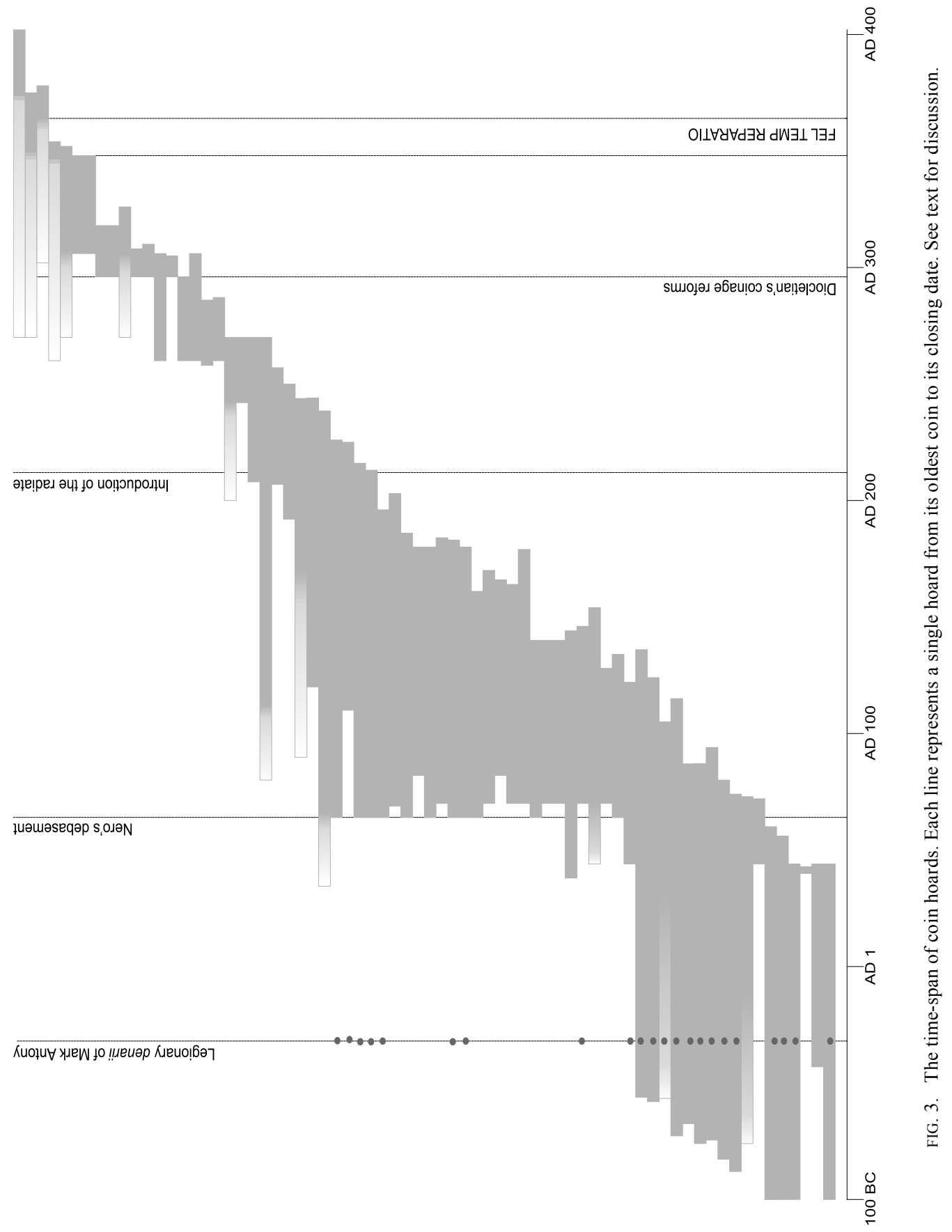


of coin use, rather than coinage data simply being used to phase and date the excavation. A similar methodology has been adopted in the analysis of finds from Butrint. ${ }^{53}$ The recent volume on excavations in Southwark integrates the coinage and pottery data in the discussion of the stratigraphy in an excellent fashion, but does not integrate those sources of information in the discussion of the coins, presumably due to the above-mentioned funding constraints. ${ }^{54}$ Recent work by David Wythe has shown that the patterns of residuality at temple sites in Britain have much to offer in the interpretation of site finds from those sites. ${ }^{55}$ The future lies, I believe, in the integration of stratigraphic, coinage, and other evidence such as ceramic data. This is hardly a revolutionary idea, being commonplace in other contexts, but one which we must now pursue with some vigour.

\section{IMPLICATIONS AND INTERPRETATION}

Why should non-numismatically-inclined archaeologists care about the arguments outlined above? A number of reasons can be adumbrated. First and most prosaically is cost. Should the English Heritage guidelines be followed precisely, coin reports will become more expensive. This is not to say that they should be allowed to become substandard - accurate identification of the entire coin assemblage using standard catalogue references must be regarded as a minimum baseline - but recording otherwise unused information is a waste of resources. Use of those resources can be improved by the efficient adoption of modern technology.

Secondly, simplistic use of numismatic data in post-excavation can, potentially, mislead. Thus, integrated analysis of the coins and the pottery at Butrint has shown that fourth-century nummi circulated at least until the end of the fifth century. ${ }^{56}$ This has major implications for the dating of sites in the region as well as for our understanding of the late antique economy. Integrated analysis of ceramic and coin data may well also contribute to debates such as that regarding 'long-lived samian'.57

The final point is the one issue rightly ignored in the guidelines, but it is surely central to archaeological endeavour, and that is the interpretation of the material and what it can contribute to broader archaeological debates. Many scholars have argued that inter-site analyses are needed in order to make the most of archaeological data ${ }^{58}$ and in many ways numismatists such as Casey and Reece led the way. We can now clearly see the differences in profiles between different types of site and chart the spread of coin use in the province. ${ }^{59}$ Regional surveys ${ }^{60}$ are often used by others to assess patterning in data from new excavations or assemblages. For these types of analysis to continue to contribute to our understanding of the period, data must be made available in a compatible way. Within ceramic studies comparisons of entire site assemblages ${ }^{61}$ have begun to give way to more contextually focused analyses using advanced statistical methods; ${ }^{62}$ the latter contribute significantly to debates such as the origins of towns in Roman Britain. ${ }^{63} \mathrm{~A}$

3 Moorhead pers. comm.

4 Drummond-Murray et al. 2002. Use of an on-line system such as the Integrated Archaeological Database System (http://www.yorkarchaeology.co.uk/iadb.htm) should allow this sort of integrated analysis to be conducted with more ease than has been possible in the past.

55 Wythe 2005.

56 Moorhead et al. 2007.

57 Wallace 2006.

58 e.g. Pitts and Perring 2006.

59 e.g. Lockyear 2000.

60 Moorhead 2001; Davies and Gregory 1991.

61 e.g. Fulford 1989, 1991.

62 Orton et al. 1993, 175-9.

63 Pitts and Perring 2006. 
similar approach has shown that breaking down lists from sites such as Lydney reveals subtleties in patterning hitherto unsuspected. ${ }^{64}$

Quite rightly, non-numismatically-inclined archaeologists, when faced with a pattern in the coin data, ask: 'What does it mean?' So, for example, what is the significance of the concentration of Valentinianic bronzes in the West Country so brilliantly illustrated by Moorhead ${ }^{65}$ This question cannot be answered solely on the basis of the numismatic evidence and the question should be turned back. What else is happening in the archaeological record at the end of the fourth century and does the West Country stand out as being unusual in other ways? This numismatic pattern is but one strand of evidence that can contribute to furthering our understanding of the end of Roman Britain.

\section{CONCLUSION}

In summary, I consider the following points to be essential:

1. All coins from an excavation should be identified as far as is possible, not just coins from key contexts.

2. A mutually agreed data schema should be created which could be employed by specialists in the field and easily archived with organisations such as the ADS. This data schema must be independent of any particular piece of software. It would then be possible easily to create catalogues for publication, or summary lists of data for analysis, in any desired form.

3. Analysis of site finds should begin to be integrated more fully with both the stratigraphic data and other finds, especially the ceramic data. As an absolute minimum context and phase information should be included in the main catalogue and the summary coinage periods should be cross-tabulated with the site phases.

I consider the following to be desirable:

1. To encourage specialists to use the data schema noted above, a user-friendly and flexible database application should be made available. As of 2007 this could be a Microsoft Access application, given that this software package is widely available, or, perhaps preferably, a web-based system using MySQL or a similar package. This application should allow quick and easy data entry, and the production of catalogues and summary lists 'at the click of a [mouse] button'.

2. Some tables in this database would be common to all users, such as dates of issues or legends, and this data should be shared between all users to prevent replication of effort and ensure accuracy. With a web-based system these data would be universally available.

3. A programme of entering existing data-sets should be begun. Ideally, this would be a major funded project but existing electronic resources ${ }^{66}$ could be converted quickly and key, wellpublished lists input.

4. As new sites are brought to publication their data should be added to a growing common pool of information.

Idealistic? Perhaps. But not unfeasible, and worth striving for.

\section{Institute of Archaeology, London}

k.lockyear@ucl.ac.uk

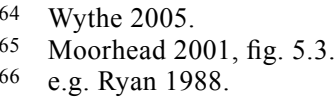




\section{BIBLIOGRAPHY}

Aitchison, J.A. 1986: The Statistical Analysis of Compositional Data, London

Baxter, M.J. 2003: Statistics in Archaeology, London

Baxter, M.J. 2006: 'Correspondence Analysis in R for archaeologists', Antiquity forthcoming

Bost, J.-P., and Namin, C. 2002: Les Monnaies, Collections du Musée archéologique départemental de Saint-Bertrand-de-Comminges 5, Saint-Bertrand-de-Comminges

Brickstock, R.J. 2002: 'The coins', in P.R. Wilson (ed.), Cataractonium: Roman Catterick and its Hinterland. Excavations and Research, 1958-1997, vol. 2, York, 1-23

Brickstock, R.J. 2004: The Production, Analysis and Standardisation of Romano-British Coin Reports, Swindon

Brickstock, R.J., and Casey, P.J. 1997: 'Roman coinage', in P. Barker, R. White, K. Pretty, H. Bird and M. Corbishley (eds), The Baths Basilica Wroxeter Excavations 1966-1990, English Heritage Archaeological Report 8, London, 264-8

Burnett, A., Jenkins, K., and Kendrick, P.M. 1986: 'Coins from the excavations', in P.M. Kendrick (ed.), Excavations at Sabratha 1948-1951, Journal of Roman Studies Monograph 2, London

Butcher, K. 2003: 'Small change in ancient Beirut. Coins from BEY 006 and 045', Berytus 45-46 (for 2001-2002)

Casey, P.J. 1994: Roman Coinage in Britain (3rd edn), Princes Risborough

Casey, P.J., and Hoffman, B. 1999: 'Excavations at the Roman temple in Lydney Park, Gloucestershire in 1980 and 1981', Antiq. Journ. 79, 81-143

Casey, P.J., and Reece, R. (eds) 1974: Coins and the Archaeologist, BAR British Series 4, Oxford

Cool, H.E.M., and Baxter, M.J. 1995: 'Finds from the fortress: artefacts, buildings and correspondence analysis', in J.W. Wilcock and K. Lockyear (eds), Computer Applications and Quantitative Methods in Archaeology 1993, BAR International Series 598, Oxford, 177-82

Cool, H.E.M., and Baxter, M.J. 1999: 'Peeling the onion: an approach to comparing vessel glass assemblages', JRA 12, 72-100

Cool, H.E.M., and Baxter, M.J. 2002: 'Exploring Romano-British finds assemblages', Oxford Journ. Arch. 21(4), 365-80

Curnow, P. 1974: 'Coin lists: some problems of the smaller site', in Casey and Reece 1974, 52-63

Curteis, M. 2005: 'The coins', in J. Hunn (ed.), Lobs Hole, Stevenage. A Romano-British Farmstead, Letchworth, 106

Davies, J.A., and Gregory, T. 1991: 'Coinage from a civitas: a survey of the Roman coins found in Norfolk and their contribution to the archaeology of the civitas Icenorum', Britannia 22, 65-101

Drummond-Murray, J., Thompson, P., and Cowan, C. (eds) 2002: Settlement in Roman Southwark. Archaeological Excavations (1991-8) for the London Underground Limited Jubilee Line Extension Project, MoLAS Monograph 12, London

Esmonde Cleary, S. 2001: 'Roman coins', in P. Leach (ed.), Excavation of a Romano-British Roadside Settlement in Somerset. Fosse Lane, Shepton Mallet 1990, Britannia Monograph 18, London, 21125

Fulford, M. 1989: 'The economy of Roman Britain', in M. Todd (ed.), Research on Roman Britain 19601989, Britannia Monograph 11, London, 175-201

Fulford, M. 1991: 'Britain and the Roman Empire: the evidence for regional and long distance trade', in R.F.J. Jones (ed.), Roman Britain: Recent Trends, Sheffield, 35-47

Guest, P.S.W. 1998: 'Discussion of the distribution of coins in and around the town', in Holbrook 1998, 262-8

Guest, P.S.W. 2005: 'The production, analysis and standardisation of Romano-British coin reports', The Archaeologist 58, 36-7

Hammerson, M.J. 1996: 'Problems of Roman coin interpretation in Greater London', in J. Bird, M. Hassall and H. Sheldon (eds), Interpreting Roman London. Papers in Memory of Hugh Chapman, Oxbow Monograph 58, Oxford, 153-64

Hammerson, M.J. 2002: 'The Roman coins', in Drummond-Murray et al. 2002, 232-40

Hill, P.V., Kent, J.P.C., and Carson, R.A.G. 1972: Late Roman Bronze Coinage, London

Hodder, I., and Reece, R. 1977: 'A model for the distribution of coins in the western Roman Empire', Journ. Arch. Science 4, 1-18 
Hodder, I., and Reece, R. 1980: 'An analysis of the distribution of coins in the western Roman Empire', Archaeo-Physika 7, 179-92

Holbrook, N. (ed.) 1998: Cirencester. The Roman Town Defences, Public Buildings and Shops, Cirencester

Lockyear, K. 1996: Multivariate Money. A Statistical Analysis of Roman Republican Coin Hoards with Special Reference to Material from Romania, unpub. Ph.D. thesis, Institute of Archaeology, University College London

Lockyear, K. 2000: 'Site finds in Roman Britain: a comparison of techniques', Oxford Journ. Arch. 19(4), $397-423$

Moorhead, T.S.N. 2001: 'Roman coin finds from Wiltshire', in P. Ellis (ed.), Roman Wiltshire and After, Devizes, $85-105$

Moorhead, T.S.N., Gjongecaj, S., and Abdy, R. 2007: 'Coins from the excavations at Butrint, Diaporit and the Vrina Plain', in I. Hansen and R. Hodges (eds), Roman Butrint, An Assessment, Oxford, 78-94

Orton, C.R., Tyers, P.A., and Vince, A. 1993: Pottery in Archaeology, Cambridge

Pitts, M. 2005: 'Regional identities and the social use of ceramics', in J. Bruhn, B. Croxford and D. Grigoropoulos (eds), TRAC 2004. Proceedings of the Fourteenth Annual Theoretical Roman Archaeology Conference, Durham 2004, Oxford, 50-64

Pitts, M., and Perring, D. 2006: 'The making of Britain's first urban landscapes: the case of Late Iron Age and Roman Essex', Britannia 37, 189-212

Ravetz, A. 1964: 'The fourth-century inflation and Romano-British coin finds', Numismatic Chronicle 124, 201-31

Reece, R. 1971: 'The coins', in B. Cunliffe (ed.), Excavations at Fishbourne, vol. 2, London, 91-100

Reece, R. 1973: 'Roman coinage in the Western Empire', Britannia 4, 227-52

Reece, R. 1974: 'Clustering of coin finds in Britain, France and Italy', in Casey and Reece 1974, 64-77

Reece, R. 1975: 'The coins', in B. Cunliffe (ed.), Excavations at Portchester Castle, London, 188-97

Reece, R. 1981: 'The Roman coins from Richborough — a summary', Bulletin Institute of Archaeology $18,49-71$

Reece, R. 1984: 'The coins', in S.S. Frere (ed.), Verulamium Excavations Volume III, Oxford, 3-17

Reece, R. 1987: Coinage in Roman Britain, London

Reece, R. 1991: Roman Coins from 140 Sites in Britain, Cotswold Studies IV, Cirencester (provisional edn)

Reece, R. 1993: 'British sites and their Roman coins', Antiquity 67, 863-9

Reece, R. 1995a: 'Roman coin hoards in Dacia and beyond', Studii şi Cercetări de Numismatică 11, 107-18 (published 1997)

Reece, R. 1995b: 'Site-finds in Roman Britain', Britannia 26, 179-206

Reece, R. 1998a: 'The catalogue and its use in the future', in Holbrook 1998, 268-90

Reece, R. 1998b: 'The excavated coins considered as groups', in Holbrook 1998, 247-62

Reece, R. 2003: 'Comparing coin finds at St-Bertrand-de-Comminges and Toulouse, and setting them in their empire-wide context', JRA 16, 611-23

Rhodes, M. 1991: 'The Roman coinage from London Bridge and the development of the City and Southwark', Britannia 22, 179-90

Rogers, G. 1998: 'Expert systems in sigillata and numismatic studies', in J. Bird (ed.), Form and Fabric. Studies in Rome's Material Past in Honour of B.R. Hartley, Oxford, 179-82

Ryan, N.S. 1982: 'Characterising fourth century coin loss: an application of principal components analysis to archaeological time-series data', Science and Archaeology 24, 25-32

Ryan, N.S. 1988: Fourth Century Coin Finds in Roman Britain: a Computer Analysis, BAR British Series 183, Oxford

Schulzki, H.-J. 1989: Die Fundmünzen der römischen Straßenstation Flerzheim, Köln

Smith, C.R. 1840: 'List of coins recently found near Strood', Numismatic Chronicle 2, 112-24

St O’Neil, B.H. 1935: 'Coins and archaeology in Britain', Arch. Journ. 92, 64-80

Volk, T.R. 1994-5: 'Retroconversion and the numerical analysis of Roman Republican coin-hoards. Part I', Rivista Italiana di Numismatica 96, 105-86

Wallace, C. 2006: 'Long-lived samian?' Britannia 37, 259-72

Wythe, D. 2005: An Analysis of Coin Finds from Seventy-Five Roman Temple Sites in Britain, unpub. undergraduate dissertation, Birkbeck College, London 